\title{
Wind Turbine Blades: An End of Life Perspective
}

\author{
Beauson, Justine; Brøndsted, Povl
}

Published in:

MARE-WINT. New Materials and Reliability in Offshore Wind Turbine Technology

Link to article, DOI:

10.1007/978-3-319-39095-6_23

Publication date:

2016

Document Version

Publisher's PDF, also known as Version of record

Link back to DTU Orbit

Citation (APA):

Beauson, J., \& Brøndsted, P. (2016). Wind Turbine Blades: An End of Life Perspective. In W. Ostachowicz, M. McGugan, J-U. Schröder-Hinrichs, \& M. Luczak (Eds.), MARE-WINT. New Materials and Reliability in Offshore Wind Turbine Technology (pp. 421-432). Springer. https://doi.org/10.1007/978-3-319-39095-6_23

\section{General rights}

Copyright and moral rights for the publications made accessible in the public portal are retained by the authors and/or other copyright owners and it is a condition of accessing publications that users recognise and abide by the legal requirements associated with these rights.

- Users may download and print one copy of any publication from the public portal for the purpose of private study or research.

- You may not further distribute the material or use it for any profit-making activity or commercial gain

- You may freely distribute the URL identifying the publication in the public portal 


\title{
Chapter 23 \\ Wind Turbine Blades: An End of Life \\ Perspective
}

\section{Justine Beauson and Povl Brøndsted}

\begin{abstract}
In 2016, the first offshore windfarm constructed in the world-located in Denmark, near Ravnsborg - is turning 25 years old, and will soon be decommissioned. After decommissioning, most of the material of the turbine can be recycled; only the composite materials found in the blades represent a challenge. This part looks at end of life solutions for this material. Wind turbine blade structure and material are described. The ends of life solutions existing and under development are detailed.
\end{abstract}

\subsection{Introduction}

Wind turbines are designed to have a lifetime of 20 years (Nijssen and Brøndsted 2013). In this period of time, the turbines can be inspected and some components can be replaced or repaired several times. The blades, for example, can be damaged by hostile weather conditions, impacts or other. However, there can be other reasons for decommissioning a windfarm than the age or the damage state of the turbines. A wind farm can also be repowered with newer and bigger turbines.

A wind turbine is basically composed of a rotor, a nacelle, a tower and a foundation. Figure 23.1 shows the weight of each part for an onshore Vestas V82 turbine (Schmidt 2006). The foundation made of concrete and steel represent nearly $80 \%$ of the structure total weight. At the end of life of the turbine, the foundation can be left in situ or destroyed and the site restored. The environmental risk associated with leaving the foundation in situ can in some cases, be considered as relatively low compared to the environmental impact generated with excavation, breaking, processing, and transporting activities needed to remove it (Welstead et al. 2013). The tower is the next largest component in terms of weight and is mainly made of steel. Metals such as steel, aluminum and copper represent $94 \%$ of the turbine weight excluding the foundation and are generally considered as materials that can be recycled (Schleisner 2000). The $6 \%$ remaining corresponds to plastic, rubber,

\footnotetext{
J. Beauson $(\bowtie) \cdot$ P. Brøndsted

Department of Wind Energy, Technical University of Denmark (DTU), DTU Risø Campus,

Frederiksborgvej 399, 4000 Roskilde, Denmark

e-mail: jube@dtu.dk; pobr@dtu.dk
} 


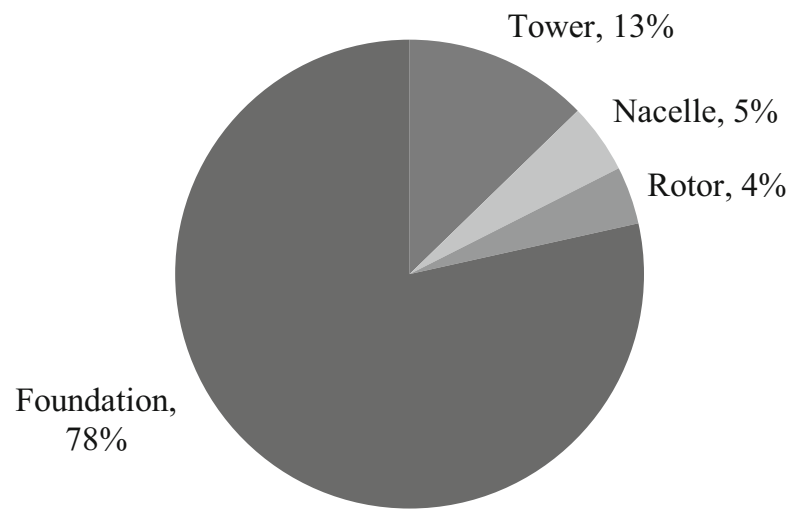

Fig. 23.1 Diagram representing the weight of the part and the corresponding percentage in a Vestas V82 onshore turbine (Schmidt 2006)

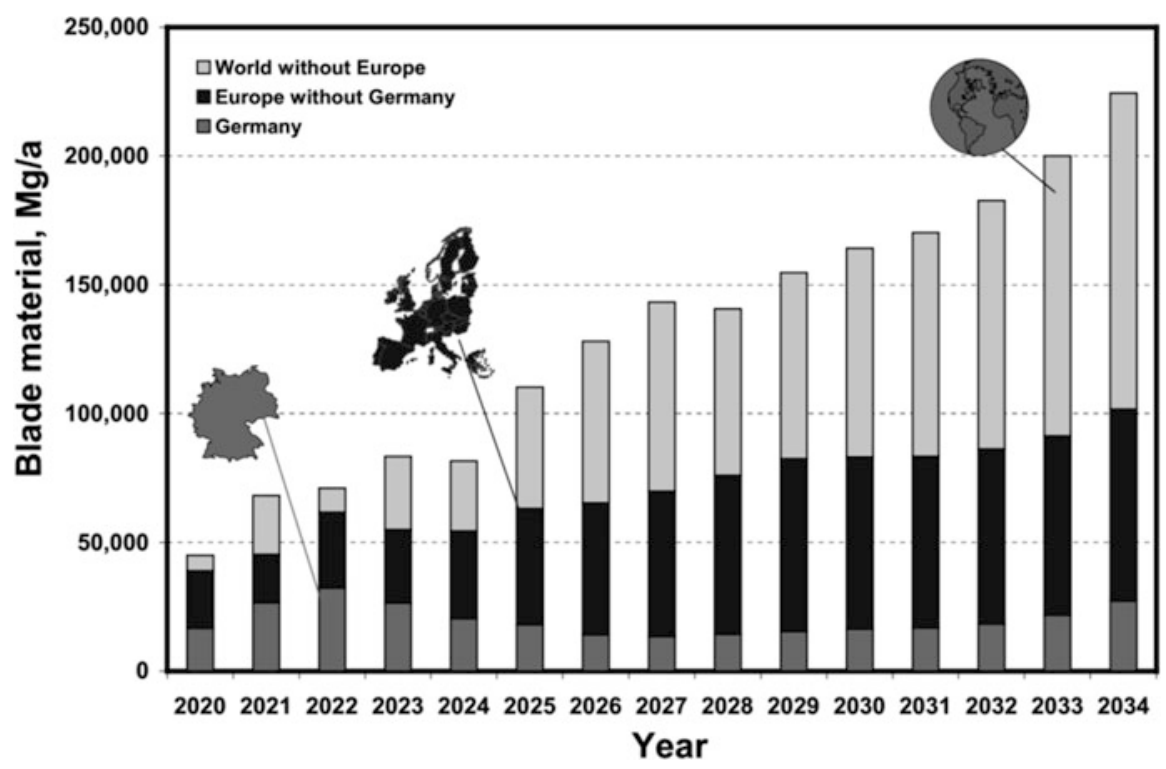

Fig. 23.2 Expected amount of end of life blade material in Germany, in Europe and worldwide from 2020 to 2034 (Albers et al. 2009)

fibre reinforced polymer composites and other. These materials are mostly found in the rotor blades and do not have established recycling solutions.

The amount of wind turbine blade material expected to reach end of life in the coming years is shown in Fig. 23.2. It is estimated to reach 50,000 tons per year in Europe, in 2022. 
In Europe, the legislation on the disposal of composite waste is mainly regulated by the waste framework and the landfill directive (Halliwell 2006). The implementations of these directives in the European countries have, for examples, led to higher tax on landfill or a prohibition to landfill in Germany. Recycling solutions for composite waste are therefore needed and research project investigating this issue are ongoing in Europe. In Denmark, the innovation consortium named GenVind (2012-2016), is looking at possible recycling solutions for wind turbine blade and other products made of glass fibre reinforced polymer composite. The project's many partners, from both industry and universities are working to develop suitable technologies and future industrial applications. This section will detail some of the outcomes of the project and other existing solution for end of life rotor blade.

This chapter is organized as follows: the wind turbine blades structure and materials are first presented. Then, the recycling solutions for wind turbine blades are presented, starting with the one implemented on an industrial scale followed by the solutions used occasionally and ending with the solutions on a research stage.

\subsection{Wind Turbine Blades: Structure and Materials}

Two parts can be distinguished in a blade, the root section and the aerodynamic section. The root section is the part of the blade connected to the turbine (Fig. 23.3a). It is tubular with a circular shape, as shown in Fig. 23.3b. The composite material used for this section is a thick unidirectional glass fiber laminate. Metallic T-bolt also named IKEA bolts or treaded bushings are inserted for mounting the blade to the hub. The root section shown in Fig. 23.3 is from a $25.8 \mathrm{~m}$ blade. It has a diameter of $1675 \mathrm{~mm}$ and a composite thickness of $80 \mathrm{~mm}$.

In the full blade length, the cross section can be designed as shown in Fig. 23.4a, with a girder box on which two aerodynamic shells are bonded, one on the suction or downwind side and one on the pressure or upwind side. The two sides are adhesively bonded to the box and at the leading and the trailing edge. In other designs the girderbox is integrated as beams in the aerodynamic profile and the two shells
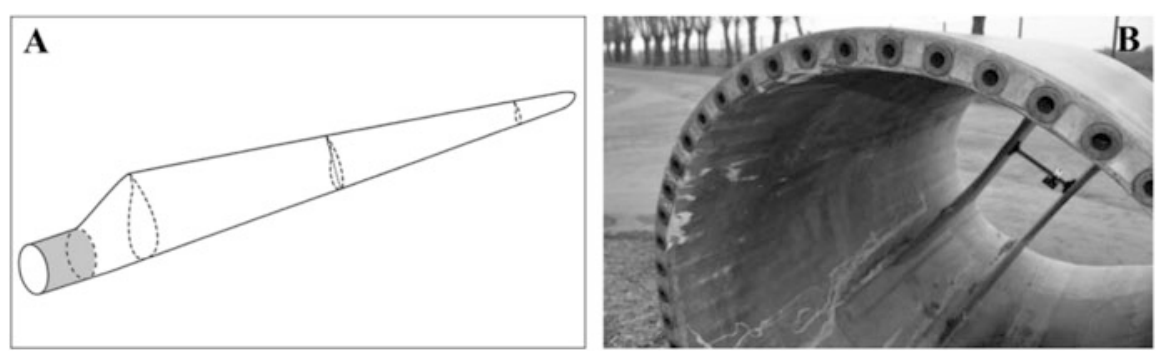

Fig. 23.3 The root section of a wind turbine blade, (a) Location of the root section, (b) Closer view of the metallic bolt 

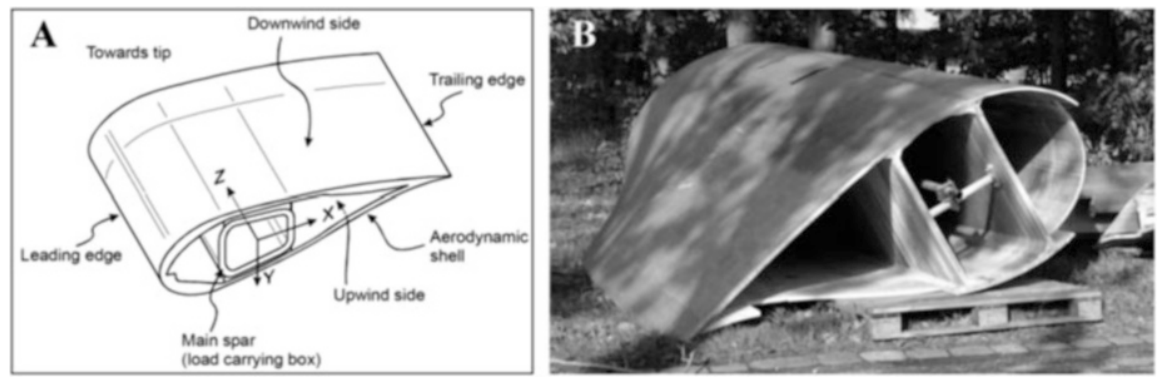

Fig. 23.4 Cross section of a blade, (a) Design with a load carrying box (Sørensen et al. 2004), (b) Design with two shear webs LM25.8

will be supported in by one or more structural shear webs (Fig. 23.4b). All these structural components are assembled using adhesive bonds.

Regarding the materials, the load carrying beam, the trailing edge and the leading edge are mostly made of unidirectional glass fibre reinforced thermoset matrix. The glass fibres used are E-glass fibres, which are inexpensive and combine high strength from 1500 to $2500 \mathrm{MPa}$ and stiffness, 72 to $76 \mathrm{GPa}$. As the trend goes towards longer blades, the weight and the stiffness of the blade become an issue. Therefore, reinforcement with a high modulus glass or a hybrid combination made of glass and carbon fibres are introduced in the composites to keep the weight down. The thermoset resins used can be epoxy, polyester or vinylester resins. The shells and the shear webs are made of sandwich structure composites, built as biaxial or multiaxial glass fiber laminates with balsa wood or polyvinyl chloride foam as core material. Surfaces are protected using gel coats, polyurethanes and thermoplastic foils or special paints are used on leading edges (Brøndsted et al. 2005).

As a part of the GenVind project, the residual strength of the composite material from a wind turbine blade after being tested in fatigue was investigated. The aim was to get an idea of the quality of real end of life composite laminate from blades. The results of these measurements demonstrate that the material is keeping its high strength and stiffness. A measurement of the porosity of the materials shows high fiber volume fraction and low porosity content. The microstructural investigation does not reveal any traces of fatigue damages due to the blade testing (Fig. 23.5).

A common size of turbine in 1990 had a power of $600 \mathrm{~kW}$ and blades length of $18 \mathrm{~m}$. In year 2015, one of the biggest turbines produced was a $7 \mathrm{MW}$ turbine with about $85 \mathrm{~m}$ long blade. The design of blade has also improved throughout the years. To ensure the lifetime of 20 years, the first blades produced were based on conservative design, using more material compared to the blade produced nowadays. Thanks to more optimized design, the blades produced nowadays are lighter (Mølholt Jensen and Branner 2013). This means that, after 20 years, the first blades produced might still be able to last a number of years more.

To summarize, blades are a complex structure made of different parts and materials, which will have different structure depending on the manufacturer and the year 


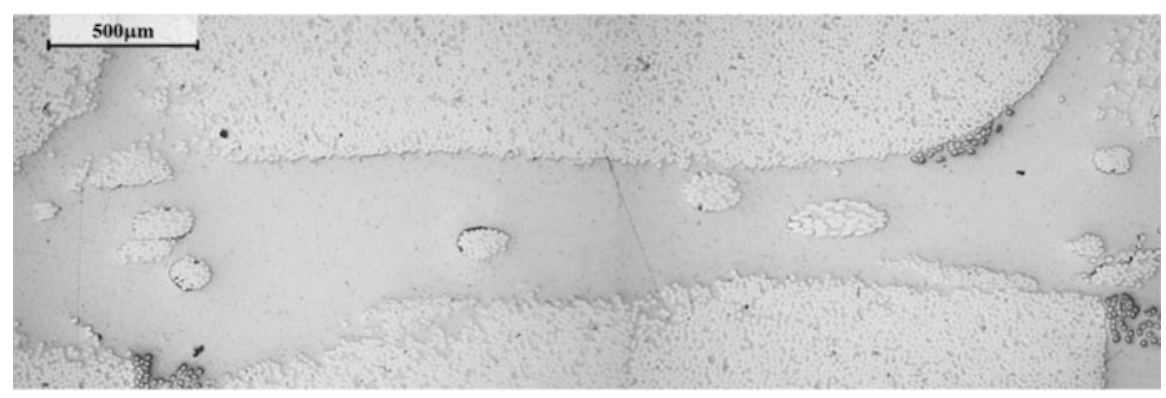

Fig. 23.5 Microstructure of a unidirectional composite from the load carrying beam

of production. When decommissioned, blades will be found in different condition depending on their design and the reason for decommissioning. Altogether, this will make recycling of blade challenging. The following part looks at solutions for end of life wind turbine blades at an industrial scale.

\subsection{Industrial Scale Solutions}

\subsubsection{Refurbishment}

The first and simplest end of life solutions for wind turbine blades is to be reused after being decommissioned. This way, their service life is extended. As previously explained, after the design lifetime of 20 years, the wind turbine blades may still have high residual capacity. A study conducted in Germany by Sayer et al. (2009) support this statement. Sayer et al. (2009) investigated the effect of service life on wind turbine blades based on the comparison of the performance of the blades after 20 years of use. The study reported no significant damages by visual inspection and no significant lost in stiffness of the blade. Therefore, reusing wind turbine and wind turbine blades is technically possible. In Europe and in Northern America, a number of companies such as Green-Ener-Tech, Repowering Solutions, Enerpower, Windturbines i.e. and Blue Planet Wind have built business on selling refurbished wind turbine. The advantages are among other an access to a wide range of proven small and medium size turbines, a short lead time and a low cost of about half the price per MW (Tucker 2009).

Standardized refurbishment procedures may include visual inspection, ultrasonic inspection, and natural frequency measurements of the blades. The blades can also be repaired, repainted, weighed and balanced (Beauson et al. 2013). Refurbishment seems technically affordable for blades with a rather small size. The companies mentioned previously handle wind turbine in the range of $10 \mathrm{~kW}$ to $1 \mathrm{MW}$. For blades longer than $50 \mathrm{~m}$, which are commonly produced nowadays, the viability of that solution might be challenged, due to transport difficulties. 


\subsubsection{Incineration}

Blade material can be incinerated for energy recovery. This solution is currently used in Denmark. It has however several drawbacks. Structural composite material, such as the one used in wind turbine blade contain up to $70 \mathrm{wt} \%$ of glass fiber. Energy recovery will be difficult, as glass fibers are not combustible and will hinder the incineration (Duflou et al. 2012). It has also been reported that the presence of glass fibre in the flue gas could disturb the gas cleaning system (Schmidt 2006). Finally, the large amounts of fly ashes, which will come from the combustion of large structure such as blade, will remain at the end of the combustion process. This residue also needs to be disposed of or used (Papadakis et al. 2010).

\subsubsection{Mechanical Grinding}

Mechanical grinding of composites consists in reducing composite waste down to pieces of a few centimeters or less. The resulting mixture, also called shredded composite, is then used in new applications. A number of companies dedicated to collect and process the composite waste brought mechanical grinding to an industrial scale. However, they all terminated, such as Phoenix Fibreglass Inc. in Canada, which was active from year 1990 to 1996 or ERCOM GmbH in Germany from 1990 to 2004.

More recently and until 2014, the company Zagons in Germany collected and grinded wind turbine blade material to be used in cement production. The procedure implemented by Zagons started by cutting the blades onsite to pieces of 10-12 m. At the factory place, these sections were further reduced to pieces of about $1 \mathrm{~m}$ in length. These smaller sections were then transformed to shredded composite material by a series of crushing and shredding steps. The resulting material had a size of $5 \mathrm{~cm}$ and was mixed with other wet waste materials. Finally, this mixture was sent to the cement production factory Holcim, which used it as a substitute for fuel, to reduce coal-ash, and as a raw material to replace virgin washed sand (Job 2013). Since 2012, using composite waste in the production of cement is considered as a viable recycling solution by the European Union (European Commission Directorate General Environment 2012; European Composites Industry Association 2013). Unfortunately, Zagons was the only industrial scale factory able to process end of life wind turbine blade for cement production worldwide.

The main challenge of this recycling solution is to find applications for the shredded composite material. Apart from the cement production, reinforcement of concrete and polymer composite have also been investigated. However, published results on concrete reinforced with shredded composite underline the need for a consistent quality of shredded composite to observe improved properties of concrete (Asokan et al. 2009). Reinforcement of polymer composite with shredded composite does not provide better results. Shredded composite is a dry material 

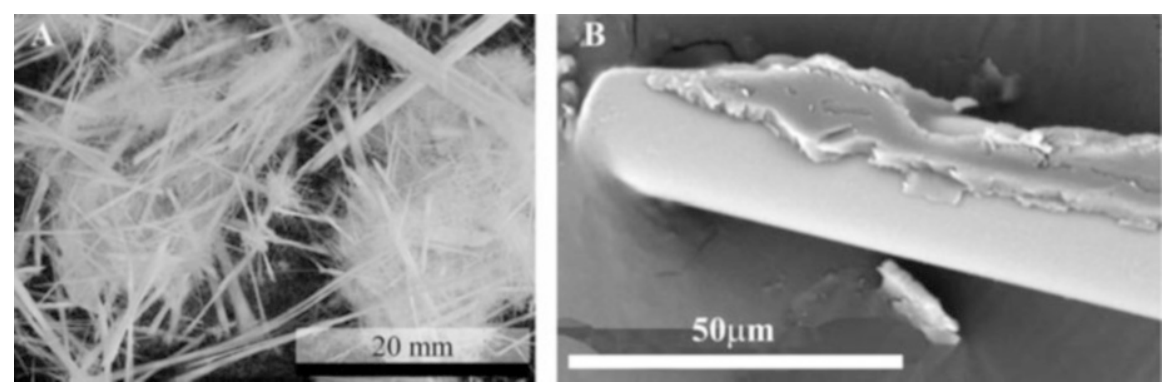

Fig. 23.6 Shredded composite, (a) Shredded composite from unidirectional glass fiber composite, (b) A glass fiber from shredded composite covered with old matrix material (Toncelli 2014)

which needs a lot of resin to be impregnated properly (Fig. 23.6a). A study conducted under the GenVind project investigated the quality and the performance of composite manufactured with shredded composite. The conclusion is that the shredded composite shows no adherence to the new polymer matrix, because the fibres present in the shredded composite are covered with old matrix material (Fig. 23.6b). The resulting composite tensile strength is very low (Toncelli 2014).

Shredded composite can also be used in sound insulation panel, by using glue to agglomerate it. This is currently under development by a Danish company named Miljøskærm (Friis Farsøe 2013). Mass production is not available yet.

Grinding wind turbine blade material has one considerable drawback; it does not take advantage of the initial structural properties of the composite and reduces considerably the value of the material. The next solutions presented look at reusing the structure and the properties of these composites. These solutions benefits from the capacity of the material, but are difficult to implement on an industrial scale. These solutions are named occasional solutions.

\subsection{Occasional Solutions}

\subsubsection{Large Sections}

Large sections of wind turbine blades can be reused for architectural or other structural purposes. This solution offers the possibility to use the good quality and the structural capacity of the blade material. It also extends the life of the material with little re-processing. On the other hand, the number of possible applications is limited by the complexity of the structure of the blade and a mass production is close to impossible. To industrialize such solution a reliable source of material with given dimension is needed, and this is difficult with end of life wind turbine blade. Examples of occasional applications have been proposed by the SuperUse studio in the Netherlands. These are a playground for children (Fig. 23.7a) or benches on a 

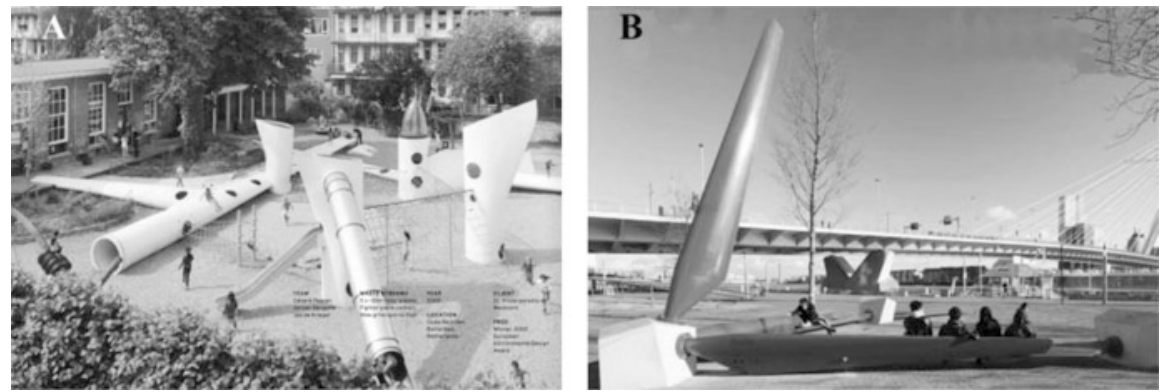

Fig. 23.7 Examples of applications for large sections of wind turbine blades by the SuperUse studio, (a) Wikado playground in Rotterdam, (b) Benches at Willemsplein in Rotterdam
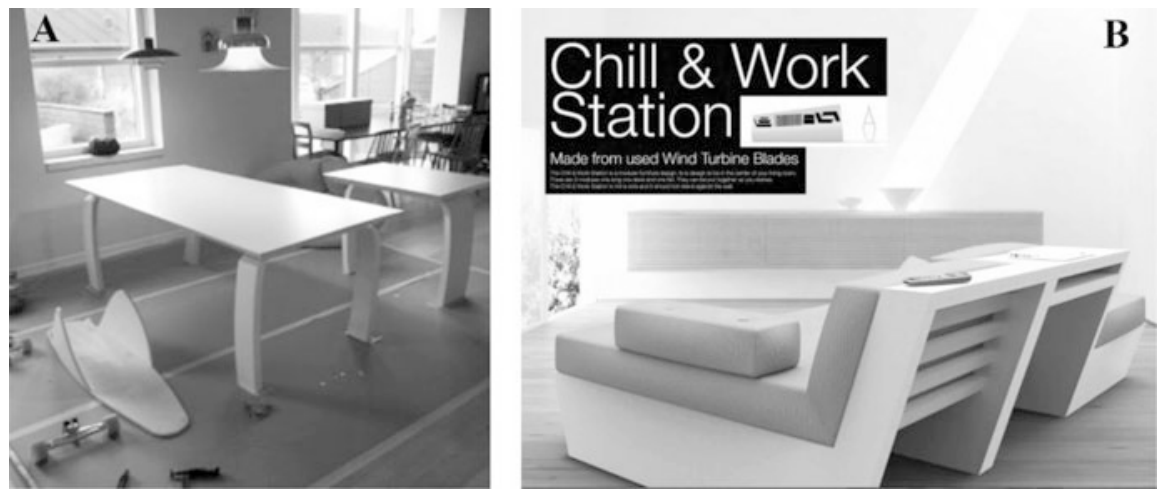

Fig. 23.8 Furniture made out of end of life wind turbine blades by Wigh Design, (a) Table and longboard, (b) Prototype of furniture

public place (Fig. 23.7b). Within the GenVind project, a bridge is under planning by the same Dutch architectural studio. The bridge will use two blades from Siemens Wind Power and will be located in Aalborg in Denmark.

\subsubsection{Construction Element}

Construction elements such as beams, plates and curved elements can also be cut out of the blades. This requires heavier reprocessing and the geometries of these elements are also restricted by the blade structure. However, the production of such standard element could diversify the possible applications. The use of such material in furniture has been investigated by Lars Wigh in the GenVind project, as shown in Fig. 23.8. Similar to the use of large section of wind turbine blade, industrialization 
of this recycling solution would also require having a reliable source of wind turbine blade material with known dimensions.

\subsection{Solutions on a Research Stage}

The last recycling solutions presented in this chapter are the ones requiring the heaviest re-processing and still mostly exist on a research stage; these solutions do not exist, or have not been trialed, on a commercial scale yet. Research on composite recycling technique has been ongoing for more than 20 years (Job 2013; Pickering 2006). The techniques are usually divided into two categories: the thermal and the chemical recycling processes. The thermal recycling techniques are for example pyrolysis or fluidized bed and allow recovering of the fibers mainly. Pyrolysis is the decomposition of organic molecules to smaller ones in an inert atmosphere with processing temperature ranging from 300 to $700{ }^{\circ} \mathrm{C}$ depending on the heating system used and the presence of a catalyst (Allred and Busselle 2000; Åkesson et al. 2012). Pyrolysis was once used on a commercial scale by ReFiber, a Danish company recycling wind turbine blade into glass fiber insulation material. The company stopped its activities in 2007 . The fluidised bed is a thermal oxidative process with a processing temperature around $450{ }^{\circ} \mathrm{C}$. The main disadvantage of these thermal recycling techniques is the reduction by a factor two or more of the glass fiber tensile strength (Kennerley et al. 1998; Thomasson et al. 2014).

Regarding the chemical recycling techniques, the most advanced and promising one is probably supercritical fluids, which uses both heat and chemicals. Supercritical fluids are fluids at temperature and pressure just above the critical point, where the fluid presents itself in one single supercritical phase, having combined characteristics: liquid like density, dissolving power, diffusivity and gas like viscosity (Oliveux et al. 2012). With this technique both the resin and the fibers can be recovered. This technique also investigated under the GenVind project has shown that glass fibers can be recovered with most of their initial tensile strength (unpublished work).

These recycling techniques are meant to enable the reuse of recycled glass fibres in new polymer composite. However, the decreased tensile strength of the fibers, the degraded surface properties (loss of the silane coupling agent) and the cost of these fibers, more expensive than pristine fibers, make it difficult.

\subsection{Conclusion}

Wind turbine blades are a complex structure made of different composite materials. They are built according to different design and are produced at different length. In addition, windfarms will be decommissioned at different time and for different reasons. End of life wind turbine blades material is therefore a discontinuous and 
inhomogeneous source of material. Altogether, this makes end of life wind turbine blade a material challenging to recycle. This section reviewed recycling solutions which are used or could be potentially be used nowadays.

The potential of these recycling solutions can be compared on: the amount of reprocessing involved, the value of the material produced and the number of possible applications. Ideally, a recycling solution would involve little reprocessing to produce a cheap valuable material, which can be used in many applications.

Considering the amount of reprocessing needed in the different solutions presented, refurbishment is certainly the one requiring the less, compared to a process like mechanical grinding or supercritical fluids. When comparing the value of the material produced, here again, refurbishment, by renewing blades which will produce electricity for a couple of more years is probably of higher value than expensive recovered glass fiber with low mechanical properties. However, when considering the number of possible applications which can be made out of the material produced, the solutions involving heavy reprocessing might be more interesting. All in all, this shows that the recycling solutions presented in this section all have advantages and drawback, which could be attenuated by combining them.

Acknowledgments The authors would like to thank the innovation consortium GenVind ("Nationalt initiativ omkring genanvendelse af plastkompositter"): especially Karin Magelund Møller and Jacob Boutrup from LM Wind Power, for providing a wind turbine blade to this study. The research has been supported by The Danish Council for Technology and Innovation under the Ministry of Science, Innovation and Higher Education.

Open Access This chapter is distributed under the terms of the Creative Commons AttributionNonCommercial 4.0 International License (http://creativecommons.org/licenses/by-nc/4.0/), which permits any noncommercial use, duplication, adaptation, distribution and reproduction in any medium or format, as long as you give appropriate credit to the original author(s) and the source, provide a link to the Creative Commons license and indicate if changes were made.

The images or other third party material in this chapter are included in the work's Creative Commons license, unless indicated otherwise in the credit line; if such material is not included in the work's Creative Commons license and the respective action is not permitted by statutory regulation, users will need to obtain permission from the license holder to duplicate, adapt or reproduce the material.

\section{References}

Åkesson D, Foltynowicz Z, Christeen J et al (2012) Microwave pyrolysis as a method of recycling glass fibre from used blades of wind turbines. J Reinf Plast Compos 31:1136-1142

Albers H, Greiner S, Seifert H et al (2009) Recycling of wind turbine rotor blades - fact or fiction? DEWI Mag 34:32-41

Allred RE, Busselle LD (2000) Tertiary recycling of automotive plastics and composites. J Thermoplast Compos Mater 13:92-101

Asokan P, Osmani M, Price ADF (2009) Assessing the recycling potential of glass fibre reinforced plastic waste in concrete and cement composites. J Clean Prod 17:821-829

Beauson J, Ilsted Bech J, Brøndsted P (2013) Composite recycling: characterizing end of life wind turbine blade material. In: Van Hoa S, Hubert P (eds) Proceedings of the 19th international 
conference on composite materials 2013 (ICCM-19), Montreal, 2013

Brøndsted P, Lilholt H, Lystrup A (2005) Composite materials for wind power turbine blades. Annu Rev Mater Res 35:505-538

Duflou JR, Deng Y, Van Acker K et al (2012) Do fiber reinforced polymer composites provide environmentally benign alternatives? A life cycle assessment based study. Mater Res Soc Bull 37:374-382

European Commission Directorate General Environment (2012) Guidance on the interpretation of key provisions of Directive 2008/98/EC on waste. In: European Commission, environment, framework Directive on waste. Available via the EC Directorate-General Environment. http:// ec.europa.eu/environment/waste/framework/pdf/guidance_doc.pdf. Accessed 12 Apr 2016

European Composites Industry Association (2013) Composite recycling made easy. In: European Composites Industry Association (EuCIA) sustainability. Available via EuCIA. http://www. avk-tv.de/files/20130212_recycling_made_easy.pdf. Accessed 12 Apr 2016

Friis Farsøe L (2013) Gamle vindmøllevinger får nyt liv i støjskærme. http://www.plast.dk/aktuelt/ nyhed/Gamle-vindmoellevinger-faar-nyt-liv-i-stoejskaerme. Accessed 12 Apr 2016

Halliwell S (2006) End of life options for composite waste: recycle, reuse or dispose? National Composite Network best practice guide. In: End of life options. Available via Composites UK. https://compositesuk.co.uk/system/files/documents/endoflifeoptions.pdf. Accessed $12 \mathrm{Apr}$ 2016

Job S (2013) Recycling glass fibre reinforced composites - history and progress. Reinf Plast 57(5):19-23

Kennerley JR, Kelly RM, Fenwick NJ et al (1998) The characterization and reuse of glass fibres recycled from scrap composites by the action of a fluidized bed process. Compos Part A 29A:839-845

Mølholt Jensen F, Branner K (2013) Introduction to wind turbine blade design. In: Brøndsted P, Nijssen RPL (eds) Advances in wind turbine blade design and material. Woodhead Publishing Limited, Cambridge, pp 3-28

Nijssen RPL, Brøndsted P (2013) Fatigue as a design driver for composite wind turbine blades. In: Brøndsted P, Nijssen RPL (eds) Advances in wind turbine blade design and material. Woodhead Publishing Limited, Cambridge, pp 175-209

Oliveux G, Bailleul JL, Le Gal La Salle E (2012) Chemical recycling of glass fibre reinforced composites using subcritical water. Compos Part A 43:1809-1818

Papadakis N, Ramirez C, Reynolds N (2010) Designing composite wind turbine blades for disposal, recycling or reuse. In: Goodship V (ed) Management recycling and reuse of waste composites. Woodhead Publishing Limited, Cambridge, pp 443-457

Pickering S (2006) Recycling technologies for thermoset composite materials - current status. Compos Part A 37:1206-1215

Sayer F, Bürkner F, Blunk M et al (2009) Influence of Loads and environmental conditions on material properties over the service life of rotor blades. DEWI Mag 34:24-31

Schleisner L (2000) Life cycle assessment of a wind farm and related externalities. Renew Energ 20:279-288

Schmidt A (2006) Life cycle assessment of electricity produced from onshore sited wind power plants based on Vestas V82-1.65 MW turbines. In: Vestas reports. Available via Vestas. https://www.vestas.com/ /media/vestas/about/sustainability/pdfs/lca\%20v82165 $\% 20 \mathrm{mw} \% 20$ onshore2007.pdf. Accessed 12 Apr 2016

Sørensen BF, Jørgensen E, Debel CP et al (2004) Improved design of large wind turbine blade of fibre composites based on studies of scale effects (Phase 1) Summary report Ris $\varnothing-\mathrm{R}-1390$. In: Research reports, DTU Orbit - The Research Information System. Available via DTU. http://orbit.dtu.dk/fedora/objects/orbit:90493/datastreams/file_7702048/content. Accessed 12 Apr 2016

Thomasson JL, Yang L, Meier R (2014) The properties of glass fibres after conditioning at composite recycling temperatures. Compos Part A 61:201-208

Toncelli C (2014) Reuse of shredded composite in new polymer composite. Dissertation, Technical University of Denmark 
Tucker L (2009) Old turbines get a second wind through remanufacturing. http://green. blogs.nytimes.com/2009/01/26/old-turbines-get-a-second-wind-through-remanufacturing/. Accessed 17 Mar 2016

Welstead J, Hirst R, Keogh D et al (2013) Research and guidance on restoration and decommissioning of onshore wind farms. In: Scottish Natural Heritage (SNH) Publications. Available via SNH. http://www.snh.org.uk/pdfs/publications/commissioned_reports/591.pdf. Accessed 12 Apr 2016 